\title{
DEPENDENCE OF TAUTOMERISM ON SUBSTITUENT TYPE IN $o$-HYDROXY SCHIFF BASES
}

\author{
Çiğdem Albayrak Kaştaş ${ }^{1}$, Gökhan Kaştaş2,"* \\ ${ }^{1}$ Sinop University, Faculty of Arts and Sciences, Department of Chemistry, Sinop, Turkey \\ ${ }^{2}$ Samsun University, Faculty of Aeronautics and Astronautics, Department of Aircraft Maintenance, \\ Samsun, Turkey \\ kastasgokhan@gmail.com
}

\begin{abstract}
Quantum computational methods were used to elucidate the structures of the $o$-hydroxy Schiff bases with different substituents. It is possible for a Schiff base to have different tautomeric structures depending on intramolecular proton transfer from the phenolic oxygen atom to the nitrogen atom. Proton transfer results in two tautomeric structures known as the phenol-imine and keto-amine forms. To explain the substituent effect on the proton transfer process in five $o$-hydroxy-Schiff bases, possible geometric structures in gas phase were optimized using density functional theory (DFT) at the B3LYP/6-311G(d,p) level. To describe tautomerism including intramolecular proton transfer, potential energy surface (PES) scans were performed starting from the optimized geometry of the phenol-imine form. HOMA indices were calculated in order to estimate $\pi$-electron delocalization. In addition, the substituent effect on the tautomerization rate was examined using Hammett substituent constants and calculating the activation energies.
\end{abstract}

Keywords: Schiff base; tautomerism; phenol-imine; keto-amine; DFT; PES

\section{ЗАВИСНОСТ НА ТАВТОМЕРИЈАТА ОД ТИПОТ НА СУПСТИТУЕНТОТ КАЈ о-ХИДРОКСИ ШИФОВИ БАЗИ}

Со примена на квантнопресметковни методи беа определени структурите на $о$-хидрокси Шифовите бази со различни супституенти. Шифовите бази можат да имаат различни тавтомерни структури во зависност од интрамолекулскиот пренос на протон од фенолниот кислороден атом на азотниот атом. Преносот на протон резултира во две тавтомерни структури познати како фенолиминска и кето-аминска форма. За да се објасни ефектот на супституентот на процесот на пренос на протон кај пет $о$-хидрокси Шифови бази, беа оптимизирани петте можни геометриски структури во гасна фаза со употреба на теоријата на функционалот на густината (DFT) на B3LYP/6-311G(d,p) ниво. За да се опише тавтомеријата вклучувајќи го и интрамолекулскиот пренос на протон, беше извршен скен на површината на потенцијалната енергија (PES) почнувајќи од оптимизираната геометрија на фенол-иминската форма. Со цел да се процени делокализацијата на $\pi$-електроните, беа пресметани индексите НОМА. Покрај тоа, беше испитан ефектот на супституцијата врз брзината на тавтомеризацијата со примена на Хаметовите супституциски константи и со пресметување на активационите енергии.

Клучни зборови: Шифови бази; тавтомерија; фенол-имин; кето-амин; DFT; PES 


\section{INTRODUCTION}

An $o$-hydroxy Schiff base can have two tautomeric structures, known as the phenol-imine and keto-amine forms. The hydrogen atom in the phenol-imine form is located on the phenolic oxygen atom, while it is on the nitrogen atom in the ketoamine form [1-3]. Proton transfer from the oxygen atom to the nitrogen atom causes tautomerism, which is responsible for the photochromic and thermochromic properties of these compounds. The photochromic character of Schiff bases is due to the transfer of protons from the oxygen atom to the nitrogen atom by the light effect, and the thermochromic property occurs via the heat effect. Photochromic and thermochromic compounds have attracted considerable attention due to their potential applications in numerous fields such as optical switches and memories, variable electrical current, ion transport through membranes [4-6], as well as industrial [7-9], pharmaceutical [10-12], biological [13-18] and chemical applications [1923]. Previous studies have shown that $o$-hydroxy Schiff bases can have one or both of these forms in the solid state [1-3]. In addition to solvent media, the type of substituent affects tautomerism as well $[24,25]$. The abovementioned applications have drawn interest regarding the investigation of the structural properties presented by Schiff bases. Therefore, in this study, the substituent effect of both the electron donor methoxy group and the electron withdrawing nitro group on tautomerism in $o$-hydroxy Schiff bases was investigated. Studied Schiff bases have two aromatic rings. For this reason, in order to understand the contribution of the substituents in each aromatic ring on tautomerism, we used five different Schiff bases. The selected Schiff bases are shown in Scheme 1.

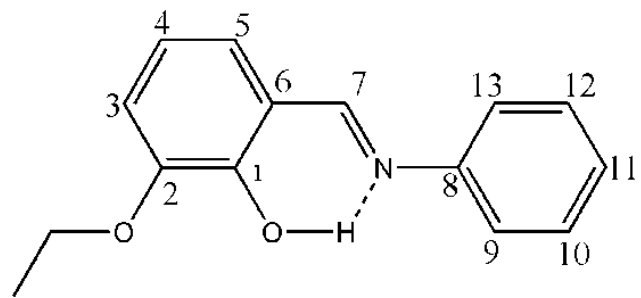

(1)

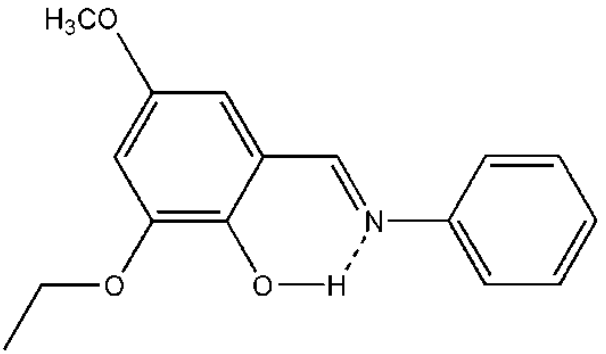

(3)

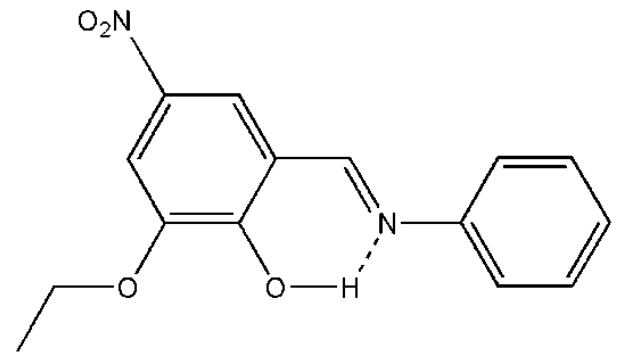

(2)

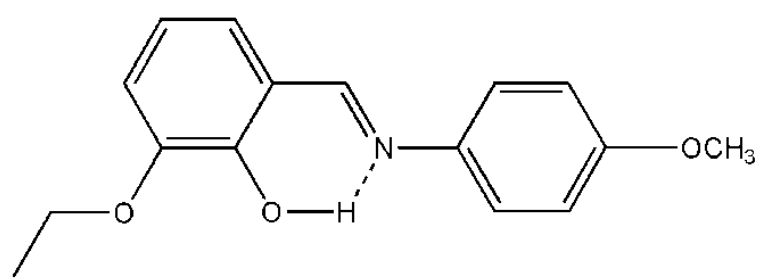

(4)

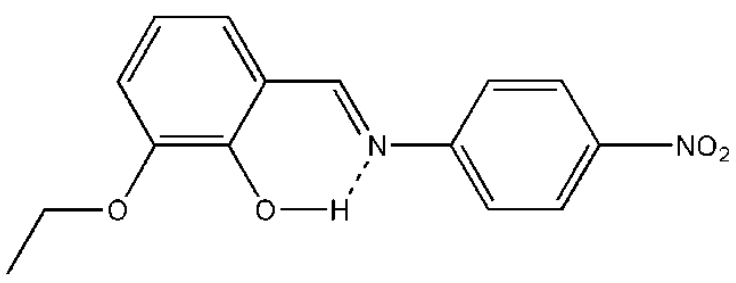

(5)

Scheme 1. Selected Schiff bases with different substituents 


\section{THEORETICAL BACKGROUND}

All calculations were performed by Gaussian 03W [26]. GaussView program was used for molecular visualization of calculated structures [27]. The geometry optimizations of two tautomers in the gas phase were carried out by DFT using the hybrid functional B3LYP (Becke's three-parameter hybrid functional with the LYP correlation functional) [28] with the 6-311G (d,p) basis set [29]. To describe tautomerism including intramolecular proton transfer, potential energy surface (PES) scans were performed using the optimized geometry of the phenolimine form. The $\mathrm{O}-\mathrm{H}$ distance was selected as the redundant internal coordinate from 0.9 to $1.80 \AA$ with a step size of $0.05 \AA[30]$.

\section{RESULTS AND DISCUSSION}

\subsection{Investigation of molecular structures}

$o$-Hydroxy Schiff bases can have two different structures in both the solid state and in solvent media. These structures are known as the phenolimine form and the keto-amine form. The tautomeric proton in the phenol-imine form is located on the phenolic oxygen atom, while the proton is on the nitrogen atom in the keto-amine form. Considerable changes in the bond lengths of the compound occur with proton transfer from the oxygen atom to the nitrogen atom. On the other hand, the most important changes are seen in the aromatic ring where proton transfer takes place. The aromatic character of the phenol-imine form decreases with the formation of the keto-amine form. However, both the phenol-imine and keto-amine forms can exist in the solid state, according to X-ray studies [1-3]. In order to explain this phenomenon, the geometry optimizations of five Schiff bases with different substituents were performed using DFT calculations with the B3LYP 6-311 G(d,p) basis set. To understand the tautomerism process and its effect on molecular structure, the energy levels of tautomers were calculated. According to the results, the optimized phenol-imine tautomer, which corresponds to the global minima for all compounds, is more stable than the optimized ketoamine form, which is the local minima. The calculated geometric parameters clearly show how important it is for determining tautomers to note changes in the bond distances of $\mathrm{C}-\mathrm{O}, \mathrm{C}=\mathrm{N}$ and the aromatic ring related to proton transfer. More specifically, passing from the phenol-imine form to the keto-amine form, the single $\mathrm{C}-\mathrm{O}$ bond length begins to shorten to the double bond length, while the double bond length $\mathrm{C}=\mathrm{N}$ begins to have a single bond character. The shortening of the $\mathrm{C} 1-\mathrm{O} 1$ and C6-C7 bond lengths, the elongation of the C7$\mathrm{N} 1$ bond lengths and changes in the bond distances of the tautomeric ring (C1-C6) clearly demonstrate the effect of the location of the proton on bond lengths. Important bond distances and energies for both the phenol-imine and keto-amine forms are given in Table 1.

\section{Table 1}

Selected bond distances $(\AA)$ and energies (a.u.) for both the phenol-imine and keto-amine forms

\begin{tabular}{ccccccc}
\hline \hline Compound & Tautomers & $\mathbf{1}$ & $\mathbf{2}$ & $\mathbf{3}$ & $\mathbf{4}$ & $\mathbf{5}$ \\
\hline \multirow{2}{*}{ C1-O1 } & Phenol-imine & 1.33718 & 1.32717 & 1.34292 & 1.33792 & 1.33598 \\
& Keto-amine & 1.25471 & 1.25000 & 1.25636 & 1.25662 & 1.25135 \\
& Phenol-imine & 1.28870 & 1.28639 & 1.28805 & 1.28903 & 1.29191 \\
\multirow{2}{*}{ C7-N1 } & Keto-amine & 1.33279 & 1.32420 & 1.33476 & 1.33024 & 1.34098 \\
& Phenol-imine & 1.41791 & 1.42379 & 1.41243 & 1.41748 & 1.41858 \\
\multirow{2}{*}{ C1-C2 } & Keto-amine & 1.46432 & 1.46784 & 1.46261 & 1.46307 & 1.46635 \\
& Phenol-imine & 1.39007 & 1.38472 & 1.39465 & 1.39033 & 1.38960 \\
\multirow{2}{*}{ C2-C3 } & Keto-amine & 1.37105 & 1.36807 & 1.37275 & 1.37188 & 1.36964 \\
& Phenol-imine & 1.40486 & 1.40313 & 1.40540 & 1.40451 & 1.40585 \\
\multirow{2}{*}{ C3-C4 } & Keto-amine & 1.43005 & 1.42650 & 1.43155 & 1.42886 & 1.43236 \\
& Phenol-imine & 1.37826 & 1.37860 & 1.38231 & 1.37869 & 1.37674 \\
\multirow{2}{*}{ C4-C5 } & Keto-amine & 1.36061 & 1.36527 & 1.36228 & 1.36163 & 1.35858 \\
& Phenol-imine & 1.41191 & 1.40323 & 1.40843 & 1.41154 & 1.41376 \\
\multirow{2}{*}{ C5-C6 } & Keto-amine & 1.4332 & 1.41836 & 1.43204 & 1.43201 & 1.43598 \\
& Phenol-imine & 1.44959 & 1.45384 & 1.45134 & 1.45039 & 1.44451 \\
\multirow{2}{*}{ C6-C7 } & Keto-amine & 1.39403 & 1.40230 & 1.39483 & 1.39666 & 1.38765 \\
\hline \multirow{2}{*}{ Energy } & Phenol-imine & -786.03487656 & -990.60156934 & -900.58680019 & -900.59080526 & -990.59899248 \\
& Keto-amine & -786.02899070 & -990.59876938 & -900.57953378 & -900.58463072 & -990.59260640 \\
\hline \hline
\end{tabular}


The activation energy for the transition state from the global minima to local minima is significantly small and excitation can occur with a small amount of energy. As shown in Figure 1, the electron withdrawing nitro group makes the proton transfer process much easier by lowering the activation energy. On the other hand, the electron donor methoxy group increases the activation energy and the proton transfer process becomes more difficult.
The keto-amine form that occurs after proton transfer is also stabilized by the electron withdrawing group $\mathrm{NO}_{2}$ and the keto form of the compound containing the electron donating methoxy group is of higher energy. The relative activation energy and keto form energy are given in Table 2. In addition, the electron withdrawing group $\mathrm{NO}_{2}$ makes the keto-amine form more stable; that is, the formation of the keto-amine form is easier than the others.

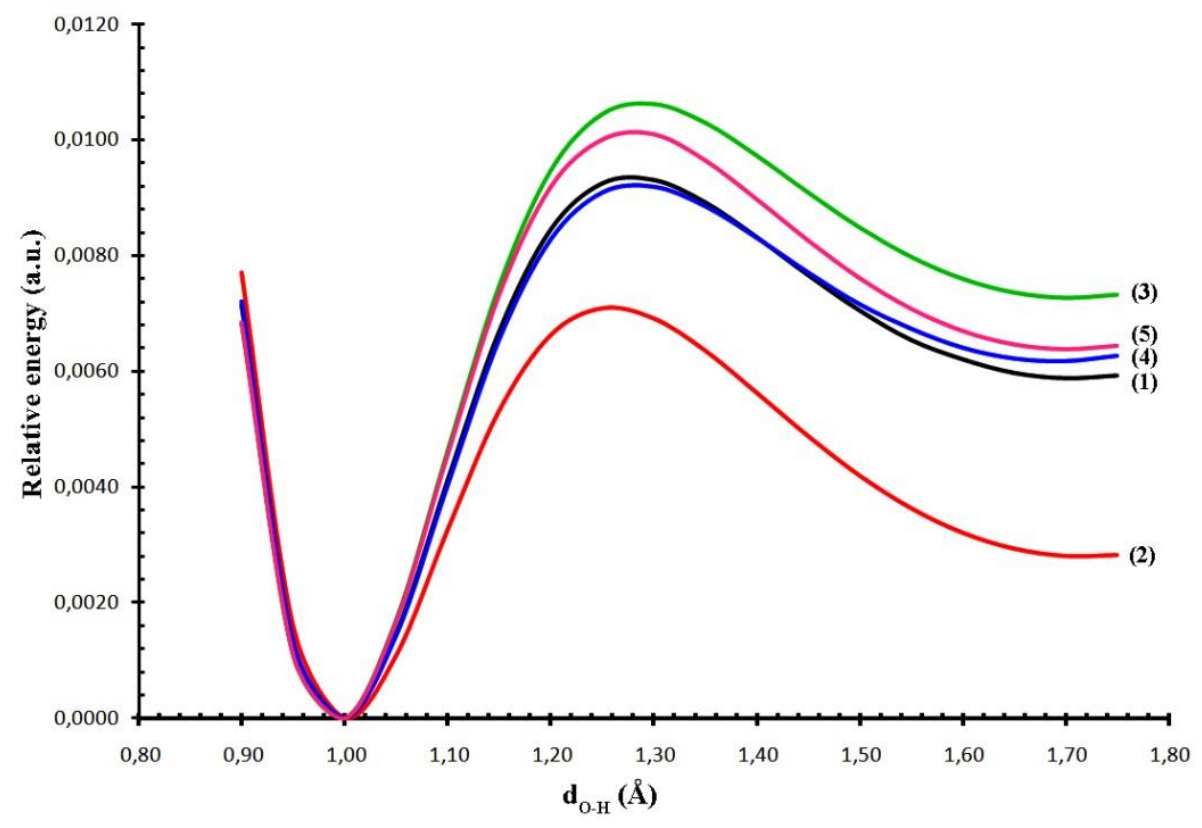

Fig. 1. Relative energy profiles during the proton transfer process.

The relative energy values were calculated relative to the energy of stable phenol-imine form.

T a b l e 2

The relative activation energies and keto form energies of the compounds

\begin{tabular}{ccc}
\hline \hline Compounds & $\begin{array}{c}\text { Relative activation energy } \\
(\mathrm{kcal} / \mathrm{mol})\end{array}$ & $\begin{array}{c}\text { Relative keto form energy } \\
(\mathrm{kcal} / \mathrm{mol})\end{array}$ \\
\hline 1 & 5.85 & 3.69 \\
2 & 4.45 & 1.76 \\
3 & 6.66 & 4.56 \\
4 & 5.77 & 3.87 \\
5 & 6.37 & 4.01 \\
\hline \hline
\end{tabular}

\subsection{Hydrogen bond properties and natural bond orbital (NBO) analysis}

When the geometric parameters in the hydrogen bond responsible for tautomerization (O$\mathrm{H} . . . \mathrm{N})$ were examined, it was seen that an elongation occurs in the $\mathrm{O}-\mathrm{H}$ bond length of compound 2, including the electron withdrawing nitro group.
This stretch is accompanied by a shortening in the distances between N...O and N...H. This is an indication that the hydrogen bond in compound 2 is stronger. The electron withdrawing effect of the nitro group causes the electron density on the oxygen to decrease. This means that the electrons of hydrogen are found more on oxygen. The hydrogen bond properties are given in Table 3 . 
Table 3

Hydrogen bond properties of the compounds

\begin{tabular}{cccc}
\hline \hline Compound & $\mathrm{O}-\mathrm{H}$ & $\mathrm{N} \ldots \mathrm{H}$ & $\mathrm{N} \ldots . . \mathrm{O}$ \\
\hline 1 & 0.99337 & 1.73477 & 2.62805 \\
2 & 0.99938 & 1.70784 & 2.60932 \\
3 & 0.99016 & 1.75514 & 2.64194 \\
4 & 0.99398 & 1.73184 & 2.32766 \\
5 & 0.99038 & 1.75119 & 2.63738 \\
\hline \hline
\end{tabular}

The second order Fock matrix was used to evaluate the donor-acceptor interactions in NBO analysis. For each donor NBO $(i)$ and acceptor NBO $(j)$, the stabilization energy $E^{(2)}$ associated with electron delocalization between donor and acceptor is estimated as

$$
E^{(2)}=\Delta E_{i j}=-q_{i} \frac{\left(F_{i j}\right)^{2}}{\varepsilon_{j}-\varepsilon_{i}}
$$

where $q_{i}$ is the donor orbital occupancy, $\varepsilon_{i}$, and $\varepsilon_{j}$ are diagonal elements (orbital energies) and $F_{i j}$ is the off-diagonal NBO Fock matrix element [31, $32]$. The larger the $E^{(2)}$ value, the more intensive the interaction between electron donors and electron acceptors, i.e., the more donating tendency from electron donors to electron acceptors and the greater the extent of conjugation of the whole system. NBO analysis for all compounds revealed that there is a strong interaction $\mathrm{LP}_{\mathrm{N} 1} \rightarrow \mathrm{BD}^{*}{ }_{\mathrm{O} 1-\mathrm{H} 1}$ $\left(\mathrm{n}_{\mathrm{N} 1} \rightarrow \sigma^{*} \mathrm{O1- \textrm {H } 1}\right)$, which corresponds to a hydrogen bond interaction. The results of the NBO analysis (Table 4) indicate that the hydrogen bond energy is increased by the electron withdrawing $\mathrm{NO}_{2}$ group. In contrast to the other compounds, compound 2 becomes stable because of a combination of lonepair electrons (LP) on $\mathrm{N}$ and an unoccupied LP* orbital on hydrogen. These phenomena can be explained by the mesomeric effect of the electron withdrawing $\mathrm{NO}_{2}$ group, as shown in Scheme 2. Accordingly, Mulliken atomic charges show that the density of electrons on oxygen atom decreases relatively in compound 2 (Table 4).
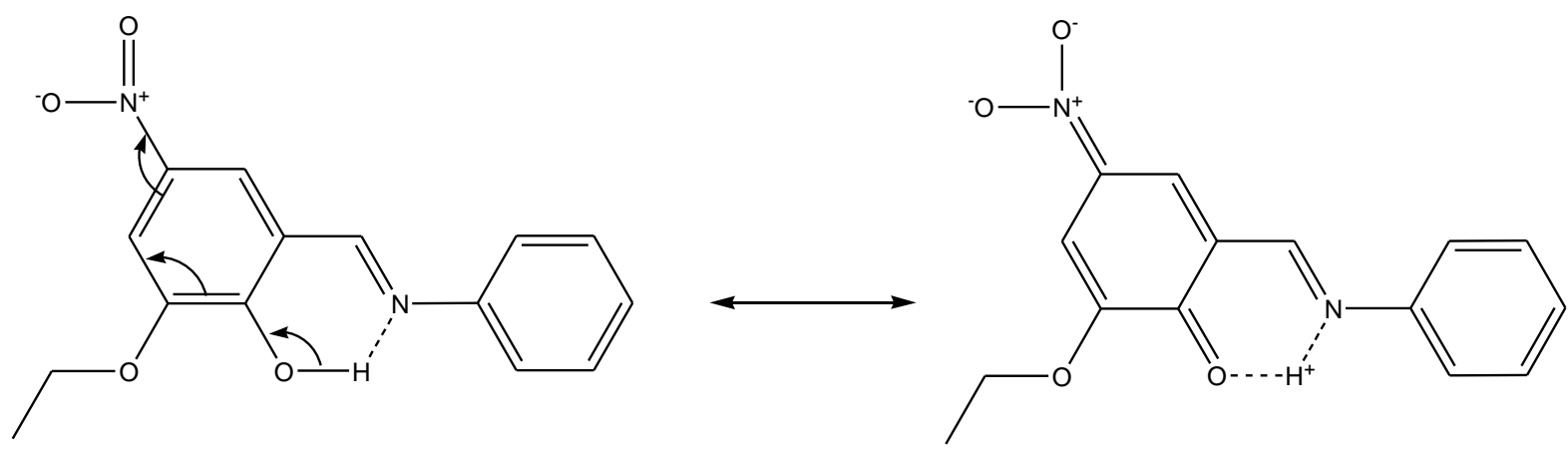

Scheme 2. Resonance structure of compound 2

Table 4

Second order perturbation theory analysis of the Fock matrix in the NBO analysis

\begin{tabular}{ccccc}
\hline \hline Compound & Donor & Acceptor & $\begin{array}{c}E^{(2)} \\
(\mathrm{kcal} / \mathrm{mol})\end{array}$ & Mulliken atomic charges \\
\hline 1 & LP(1) N1 & BD*(1)O1-H1 & 23.59 & -0.415714 \\
2 & LP(1) N1 & LP* H1 & 42.62 & -0.388220 \\
3 & LP(1) N1 & BD $^{*}(1) \mathrm{O} 1-\mathrm{H} 1$ & 21.32 & -0.420343 \\
4 & LP(1) N1 & BD*(1)O1-H1 $\left.^{*}\right)$ & 24.10 & -0.418270 \\
5 & LP(1) N1 & BD*(1)O1-H1 & 21.67 & -0.403886 \\
\hline \hline
\end{tabular}


Because of the resonance structure seen in Scheme 2, proton transfer occurs much more easily in the compounds containing an electron withdrawing group. On the contrary, the electron donor methoxy group makes it difficult for the proton to migrate onto nitrogen by increasing the electron density on the oxygen with the mesomeric effect.

\subsection{Investigation of kinetic properties}

The Hammet equation below [33] can be used to explain the effect of substituents on the reaction rate:

$$
\log k / k_{0}=\rho \sigma
$$

In the equation, $k$ is the reaction rate constant for substituted compounds, $k_{0}$ is the reaction rate constant for unsubstituted compound with $\mathrm{R}=$ $H, \rho$ is the reaction constant and $\sigma$ is the substituent constant. The reaction constant $(\rho)$ shows the effect of substituents on the reaction rate. A high $\rho$ value indicates that the reaction rate is significantly influenced by the substituents, while a small $\rho$ value indicates little effect of the substituents. $\rho<0$ values mean that the reaction is accelerated by electron donating groups, whereas $\rho>0$ values correspond to a reaction accelerated by electron withdrawing groups [34]. The Arrhenius equation is given below:

$$
k=A e^{-E_{a} / R T}
$$

where $k$ is the reaction rate coefficient, $E_{a}$ is the activation energy, $R=1.985 \times 10^{-3} \mathrm{kcal} \cdot \mathrm{mol}^{-1} \mathrm{~K}^{-1}$ and $T=298 \mathrm{~K}$. Using these two equations, one can derive the following expression in order to obtain the reaction constant $(\rho)$. First, the ratios of the rate constants are calculated using the activation energies $\left(E_{\mathrm{a}}\right)$ obtained from the proton transfer process, and then plotted against the substituent constants $(\sigma)$, as shown in Figure 2.

$$
\log k / k_{0}=\left(E_{a_{0}}-E_{a}\right) / 2.303 R T=\rho \sigma
$$

When the graph is examined, it has $\rho>0$ and specifically a high $\rho$ value for the aromatic ring I (Scheme 3). That is, the substituents in the ring I are very influential in tautomerism. While the electron withdrawing groups facilitate tautomerization, the electron donating groups make it difficult. For this reason, compounds containing an electron withdrawing group tend to form more keto-amines. Schiff bases containing an electron do- nating group are present in the phenol-imine form. However, aromatic ring III exhibits the opposite behavior. It has $\rho<0$ and small $\rho$ value. In other words, the substituents have no remarkable effect on tautomerism. Contrary to the substituents in the tautomeric ring I, electron donating groups in ring III facilitate tautomerization, but electron withdrawing groups make tautomerization difficult.

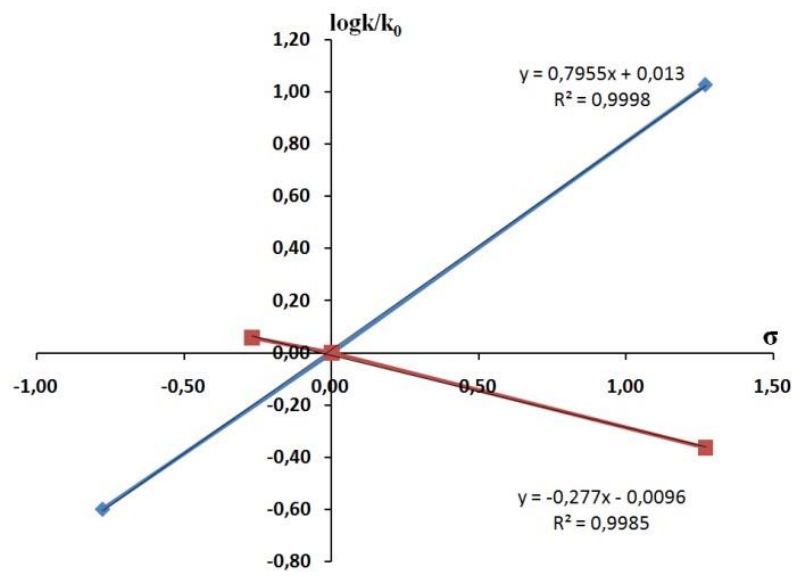

Fig. 2. The substituent effect on the reaction rate in Schiff bases

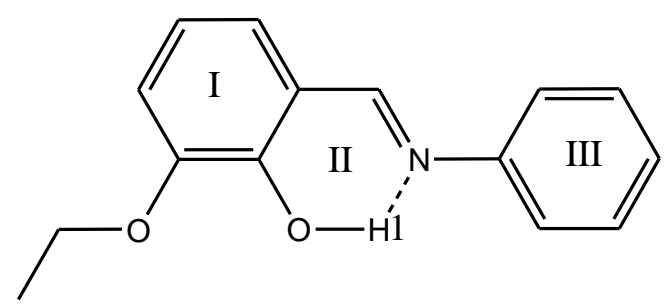

Scheme 3. Numbering of the rings (aromatic and chelate) for five Schiff bases

\subsection{Tautomerism from the perspective of the HOMA index}

The harmonic oscillator model of aromaticity (HOMA) index gives information about the aromaticity of compounds, using average squared deviation of bond lengths. The HOMA index is 1 for the pure aromatic systems. When aromaticity decreases, the HOMA index approximates to zero.

$$
\mathrm{HOMA}=1-\frac{1}{n} \sum_{j=1}^{n} \alpha_{j}\left(R_{j}-R_{o p t}\right)^{2}
$$

where $n$ is the number of bonds and $R_{j}$ is individual bond length. The normalization constant is equal to 257.7 for $\mathrm{C}-\mathrm{C}, 93.52$ for $\mathrm{C}-\mathrm{N}$ and 157.38 for $\mathrm{C}-\mathrm{O}$ bonds; the optimal value $R_{\text {opt }}=1.388 \AA$ for $\mathrm{C}-\mathrm{C}$, 
$1.334 \AA$ for $\mathrm{C}-\mathrm{N}$ and $1.265 \AA$ for $\mathrm{C}-\mathrm{O}[35,36]$. The HOMA indices of aromatic rings and chelate rings (Scheme 3) were calculated at each step of the scan process. The change in HOMA indices versus the scan coordinate is shown in Figure 3. It can be seen that the aromaticity level of C1/C6 in ring I decreases while the aromaticity level of $\mathrm{C} 8$ C13 in ring III increases slightly with the scan coordinate changing from 0.9 to $1.80 \AA$. There is a decrease in the aromaticity of ring I up to $1.30 \AA$, while there is an increase in the aromaticity of chelate ring II. The loss in aromaticity is accompanied by an increase in the chelate ring, which causes the aromaticity of the whole molecule to remain unchanged. On the other hand, aromatic ring III shows a small increase in its aromaticity. The aromaticity is decreased in both I and II after $1.30 \AA$. While the aromaticity of chelate ring II decreases slightly, it decreases significantly in aromatic ring $\mathrm{I}$.

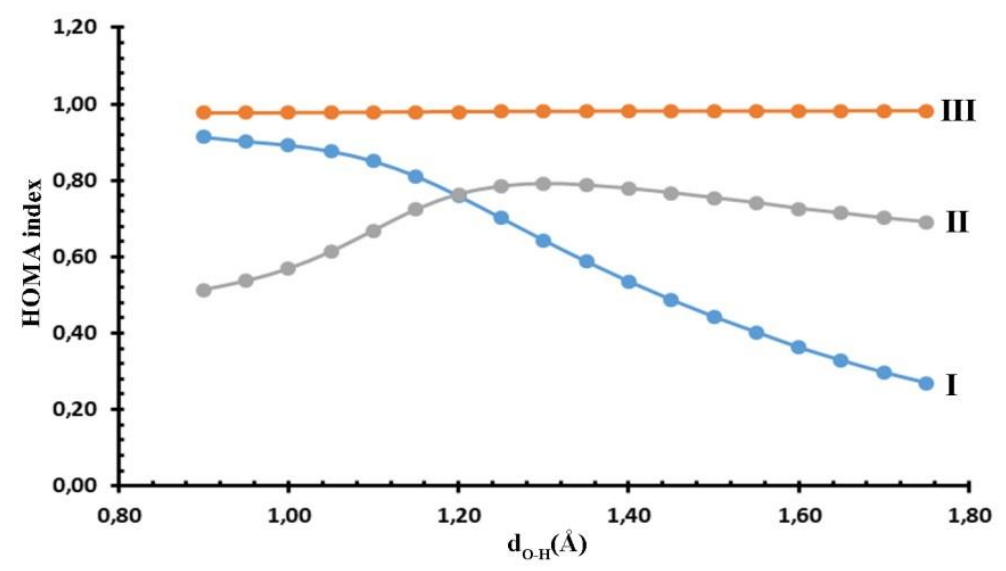

Fig. 3. The dependency of aromatic (I and III) and chelate (II) rings on the HOMA indices for compound 1

Other compounds showed similar behaviors, as seen in Figures 4 and 5. The HOMA indices show that proton transfer from the phenol-imine to keto-amine forms in $o$-hydroxy Schiff bases is facilitated by $\pi$-electron delocalization, which occurs in the aromatic (I) and chelate (II) rings (Scheme 4). This situation makes it possible to obtain the keto-amine form in the solid state and in solvent media, as previously reported in the literature, although the loss of aromaticity in the pure keto form is considerable in compounds containing both electron donating and electron withdrawing groups [37-43].

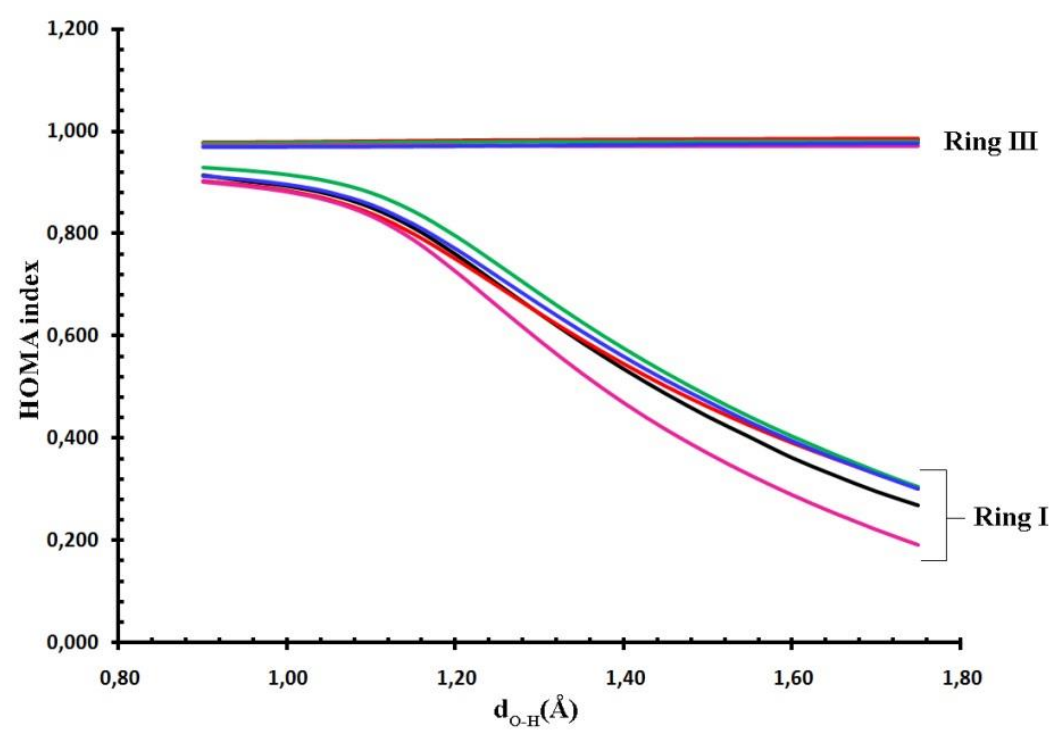

Fig. 4. The dependency of aromatic rings on the HOMA index for all compounds 


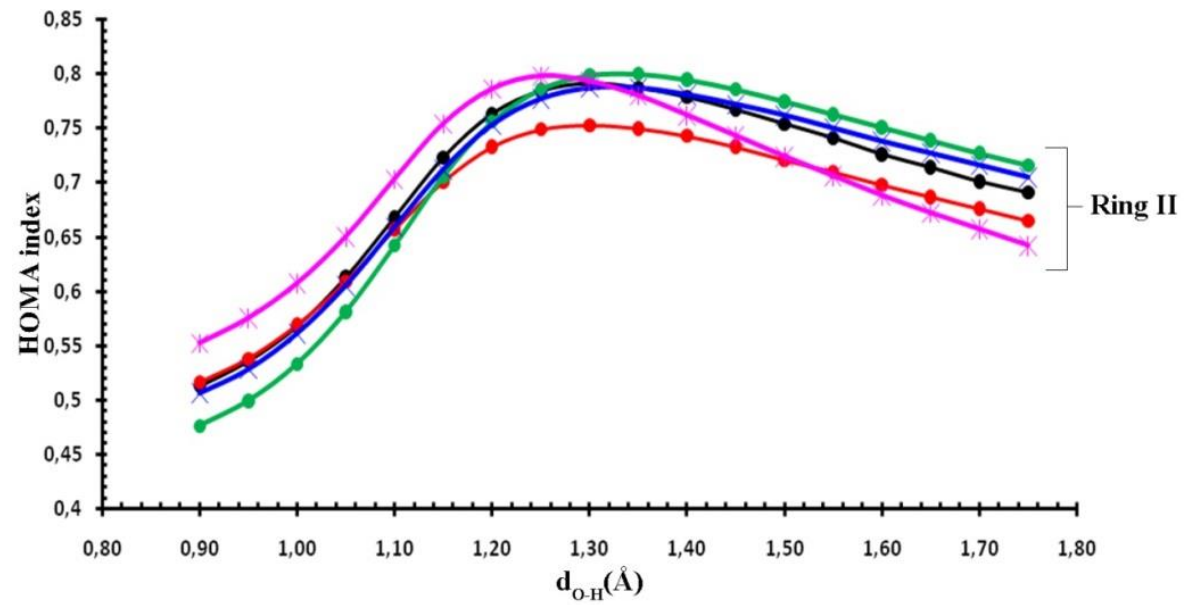

Fig. 5. The dependency of chelate rings on the HOMA index for all compounds

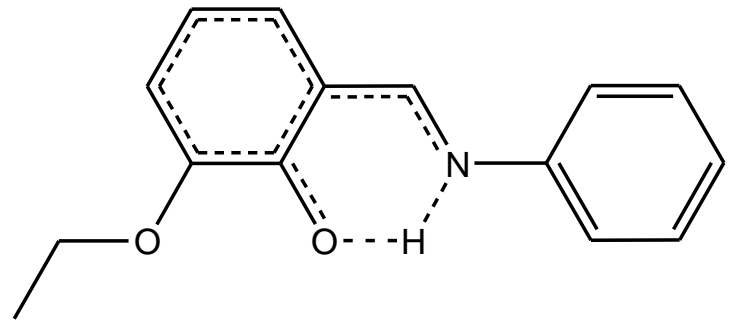

Scheme 4. $\pi$-Electron delocalization in the aromatic (I) and chelate (II) rings

\section{CONCLUSIONS}

Quantum chemical studies show that, in all compounds, the phenol-imine form is more stable than the keto-amine form. The electron withdrawing nitro group makes the proton transfer process much easier by lowering the activation energy. On the other hand, the electron donor methoxy group increases the activation energy and proton transfer becomes more difficult. This result was also confirmed by the kinetic data. The $\rho$ values obtained from the graphical method show that the substituents greatly affect aromatic ring I; while electron withdrawing groups facilitate tautomerization, electron donating groups make it difficult. For this reason, compounds containing an electron withdrawing group tend to form more keto-amines. Schiff bases containing an electron donating group are present in the form of phenol-imine. On the other hand, the substituent effect on tautomerization in aromatic ring III is very small; contrary to aromatic ring I, electron attracting groups slow down the tautomerization reaction, while electron donating groups accelerate it. Geometry-based aromaticity HOMA indices provided important information on electron delocalization in the aromatic rings. The aromatic ring $\mathrm{I}$ in the phenol- imine form for all compounds had a very high value of the HOMA index (about 0.9), indicating strong $\pi$-electron delocalization in this ring. On the contrary, the keto-amine tautomer exhibits low aromaticity (HOMA indices of about 0.3 for all compounds), and the chelate ring has relatively high electron delocalization. During tautomerization, $\pi$-electron delocalization in the phenol-imine form decreases, while $\pi$-electron delocalization in the chelate ring increases; that is, HOMA index of the chelate ring increases. These results show that proton transfer from the phenol-imine to the ketoamine form is facilitated by $\pi$-electron delocalization. This situation makes it possible to obtain the keto-amine form, although the loss of aromaticity in the pure keto form is considerable in $o$-hydroxy Schiff bases.

\section{REFERENCES}

[1] A. Özek, Ç. Albayrak, M. Odabaşoğlu, O. Büyükgüngör, Three (E)-2-[(bromophenyl)iminomethyl]-4-methoxyphenols, Acta Crystallogr., C63, o177-o180 (2007). DOI: $10.1107 /$ S0108270107003241

[2] B. Koşar, Ç. Albayrak, M. Odabaşoğlu, O. Büyükgüngör, 2-Hydroxy-6-[(2-hydroxyphenylamino) methylene]-cyclohexa-2,4-dienone, Acta Crystallogr., E61, o1097o1099 (2005). DOI:10.1107/S160053680500807X

[3] B. Koşar, Ç. Albayrak, M. Odabaşoğlu, O. Büyükgüngör, Theoretical and Experimental Studies on Electronic Structure, Cocrystallization, and Intramolecular Proton Transfer of Two Tautomers: (E)-2-\{[2-(Hydroxymethyl) phenylimino]methyl $\}-5$-methoxyphenol and (z)-6-\{[2(Hydroxymethyl)phenylamino]methylene \}-3-methoxycyclohexa-2,4-die none Int. J. Quantum Chem., 111, 3654-3663 (2011). DOI: 10.1002/qua.22789

[4] I. Moustakali-Mavridis, E. Hadjoudis, A. Mavridis, Crystal and molecular structure of thermochromic Schiff bases, Acta Crystallogr., B34, 3709-3715 (1978). DOI: doi.org/10.1107/S0567740878011930 
[5] E. Hadjoudis, M. Vitterakis, I. Moustakali-Mavridis, Photochromism and thermochromism of Schiff bases in solid state and rigid glasses, Tetrahedron, 43, 13451360 (1987). DOI: 10.1016/S0040-4020(01)90255-8

[6] H. Dürr, H. Bouas-Laurent, Photochromism: Molecules and Systems, Elsevier, Amsterdam, 1990, pp. 685-710.

[7] C. A. Mc Auliffe, R. V. Parish, S. M. Abu-El-Wafa, R. M. Issa, High-valent manganese complexes of tetradentate Schiff base ligands. ESR-active and ESRsilent dimeric species, Inorg. Chim. Acta, 115, 91-94 (1986). DOI: doi.org/10.1016/S0020-1693(00)87702-6

[8] T. Maki, H. Hashimato, Bull. Chem. Soc. Jpn. Vat dyes of acenaphthene Series. IV. Condensation of perylenetetracarboxylic Acid Anhydride with $O$ phenylenediamine, 25, 411-413 (1952).

DOI: doi.org/10.1246/bcsj.25.411

[9] S. Papie, N. Kaprivanae, Z. Grabarie, D. Paracosterman, Metal complex dyes of nickel with Schiff bases, Dyes Pigments 25, 229-240 (1994).

DOI: doi.org/10.1016/0143-7208(94)85012-7

[10] S. Zolezzi, E. Spodine, A. Decinti, Electrochemical studies of copper(II) complexes with Schiff-base ligands, Polyhedron, 21, 55-59 (2002). DOI: doi.org/10.1016/S0277-5387(01)00960-3

[11] M. Singh, Transferrin as a targeting ligand for liposomes and anticancer drugs. Curr. Pharm. Des., 5, 443-451 (1999).

[12] V. Ambike, S. Adsule, F. Ahmed, Z. Wang, Z. Afrasiabi, E. Sinn, F. Sarkar, S. Padhye, Copper conjugates of nimesulide Schiff bases targeting VEGF, $\mathrm{COX}$ and $\mathrm{Bcl}-2$ in pancreatic cancer cells, J. Inorg. Biochem., 101, 1517-1524 (2007).

DOI: $10.1016 /$ j.jinorgbio.2007.06.028

[13] C. P. Prabhakaran, C. C. Patel, $\mathrm{NN}^{\prime}$ ethylene bis (salicylideneimine) complexes of manganese (III) halides, J. Inorg. Nucl. Chem., 31, 3316-3319 (1969). DOI: doi.org/10.1016/0022-1902(69)80121-1

[14] M. R. Mahmoud, M. T. El-Haty, Cobalt(II), nickel(II), copper(II), thorium(IV) and uranium(VI) complexes of some heterocyclic Schiff bases derived from hydroxy aromatic aldehydes and 2-aminopyridine, J. Inorg. Nucl. Chem., 42, 349-353 (1980). DOI: doi.org/10.1016/0022-1902(80)80005-4

[15] Z. Cimerman, S. Miljanic, J. Antolic, Fluorescence characteristics of Schiff bases derived from amino- and aminoalkylpyridines, Spectrosc. Lett., 32, 181-196 (1999). DOI: doi.org/10.1080/00387019909349976

[16] R. D. Jones, D. A. Summervile, F. Basolo, Synthetic oxygen carriers related to biological systems, Chem. Rev., 79, 139-179 (1979). DOI: 10.1021/cr60318a002

[17] R. R. Gagne, C. I. Spiro, T. J. Smith, W. R. Homanh, W. R. Thies, K. Shiemke, The synthesis, redox properties, and ligand binding of heterobinuclear transition-metal macrocyclic ligand complexes. Measurement of an apparent delocalization energy in a mixed-valent copper(I)copper(II) complex, J. Am. Chem. Soc., 103 (1981) 4073-4081. DOI: $10.1021 / \mathrm{ja} 00404 \mathrm{a} 017$

[18] R. Atkins, G. Brfwer, E. Kokto, G. M. Mockler, E. Sinn, Copper(II) and nickel(II) complexes of unsymmetrical tetradentate Schiff base ligands, Inorg. Chem., 24, 127134 (1985). DOI: 10.1021/ic00196a003
[19] T. W. Hambley, L. F. Lindoy, J. R. Reimers, P. Turner, W. Wei, A.N.W. Cooper, Macrocyclic ligand design. Xray, DFT and solution studies of the effect of $N$ methylation and $N$-benzylation of 1,4,10,13-tetraoxa7,16-diazacyclooctadecane on its affinity for selected transition and post-transition metal ions, J. Chem. Soc., Dalton Trans. 614-620 (2001). DOI: $10.1039 / \mathrm{B} 008789 \mathrm{~K}$

[20] S. Chandra, L. K. Cupta, Spectral, physicochemical and biological characterization of 2,5,11,14,19,20-hexaaza3,12-dimethyl-4,13-dipropyl-tricyclo [13.3.1.1(6-10)] cosane-1(19),2,4,6(20),7,9,11,13,15,17-decaene and its transition metal complexes, Trans. Met. Chem., 30, 630-635 (2005).

DOI: doi.org/10.1007/s11243-005-4826-4

[21] T. M. A. Ismail, Mononuclear and binuclear $\mathrm{Co}(\mathrm{II})$, $\mathrm{Ni}(\mathrm{II}), \mathrm{Cu}(\mathrm{II}), \mathrm{Zn}(\mathrm{II})$ and $\mathrm{Cd}(\mathrm{II})$ complexes of Schiffbase ligands derived from 7-formyl-8-hydroxyquinoline and diaminonaphthalenes, J. Coord. Chem., 58 (2), 141151 (2005).

DOI: doi.org/10.1080/0095897042000274733

[22] R. R. Fenton, R. Gauci, P. C. Junk, L. F. Lindoy, R. C. Luckay, G. V. Meehan, J. R. Price, P. Tumer, G. Wei, Macrocyclic ligand design. Structure-function relationships involving the interaction of pyridinylcontaining, mixed oxygen-nitrogen donor macrocycles with cobalt(II), nickel(II), copper(II), zinc(II), cadmium(II), silver(I) and lead(II), J. Chem. Soc., Dalton Trans. 2185-2193 (2002).

DOI: $10.1039 / \mathrm{B} 201195 \mathrm{~F}$

[23] M. T. H. Tarafder, N. Saravanan, K. A. Course, Coordination chemistry and biological activity of nickel(II) and copper(II) ion complexes with nitrogen-sulphur donor ligands derived from S-benzyldithiocarbazate (SBDTC), Trans. Met. Chem., 26, 613-618 (2001). DOI: doi.org/10.1023/A:1012047001167

[24] A. Blagus, D. Cinčić, T. Friščić, B. Kaitner, V. Stilinović, Schiff based derived from hydroxyaryl aldehydes: molecular and crystal structure, tautomerism, quinoid effect, coordination compounds, Maced. J. Chem. Eng., 29, 117-138 (2010).

[25] Ç. Albayrak, G. Kaştaş, M. Odabaşoğlu, R. Frank, The prototropic tautomerism and substituent effect through strong electron-withdrawing group in (E)-5(diethylamino)-2-[(3-nitrophenylimino)methyl]phenol, Spectrochim. Acta, Part A, 114, 205-213 (2013). DOI: doi.org/10.1016/j.saa.2013.05.044

[26] M. J. Frisch, G. W. Trucks, H. B. Schlegel, G. E. Scuseria, M. A. Robb, J. R. Cheeseman, J. A. Montgomery, T. J. Vreven, K. N. Kudin, J. C. Burant, J. M. Millam, S. S. Iyengar, J. Tomasi, V. Barone, B. Mennucci, M. Cossi, G. Scalmani, N. Rega, G. A. Petersson, H. Nakatsuji, M. Hada, M. Ehara, K. Toyota, R. Fukuda, J. Hasegawa, M. Ishida, T. Nakajima, Y. Honda, O. Kitao, H. Nakai, M. Klene, X. Li, J. E. Knox, H. P. Hratchian, J. B. Cross, C. Adamo, J. Jaramillo, R. Gomperts, R. E. Stratmann, O. Yazyev, A. J. Austin, R. Cammi, C. Pomelli, J. W. Ochterski, P. Y. Ayala, K. Morokuma, G. A. Voth, P. Salvador, J. J. Dannenberg, V. G. Zakrzewski, S. Dapprich, A. D. Daniels, M. C. Strain, O. Farkas, D. K. Malick, A. D. Rabuck, K. Raghavachari, J. B. Foresman, J. V. Ortiz, Q. Cui, A. G. Baboul, S. Clifford, J. Cioslowski, B. B. Stefanov, G. 
Liu, A. Liashenko, P. Piskorz, I. Komaromi, R. L. Martin, D. J. Fox, T. Keith, M. A. Al-Laham, C. Y. Peng, A. Nanayakkara, M. Challacombe, P. M. W. Gill, B. Johnson, W. Chen, M. W. Wong, C. Gonzalez, J. A. Pople, Gaussian 03, Revision E.01. Gaussian, Inc., Wallingford CT (2004)

[27] R. Dennington II, T. Keith, J. Millam, GaussView, Version 4.1.2. Semichem Inc, Shawnee Mission, KS, (2007).

[28] P. J. Stephens, F. J. Devlin, C. F. Chabalowski, M. J. Frisch, Ab initio calculation of vibrational absorption and circular dichroism spectra using density functional force fields, J. Phys. Chem., 98, 11623-11627 (1994). DOI: $10.1021 / \mathrm{j} 100096 \mathrm{a} 001$

[29] M. J. Frisch, J. A. Pople, J. S. Binkley, Self consistent molecular orbital methods 25. Supplementary functions for Gaussian basis sets, The Journal of Chemical Physics 80, 3265 (1984). DOI: https://doi.org/10.1063/1.447079

[30] C. Peng, P. Y. Ayala, H. B. Schlegel, M. J. Frisch, Using redundant internal coordinates to optimize equilibrium geometries and transition states, J. Comp. Chem., 17, 49-56 (1996). DOI: doi.org/10.1002/(SICI)1096987X(19960115)17:1<49::AID-JCC5>3.0.CO;2-0

[31] A. E. Reed, L. A. Curtiss, F. Weinhold, Intermolecular interactions from a natural bond orbital, donor-acceptor viewpoint, Chem. Rev., 88, 899-926 (1988). DOI: $10.1021 / \mathrm{cr} 00088 \mathrm{a} 005$

[32] E. D. Glendening, C. R. Lsndis, F. Weinhold, Natural bond orbital methods, Comput. Mol. Sci. 1-42 (2011), DOI: $10.1002 /$ wcms.51

[33] L. P., Hammett, The effect of structure upon the reactions of organic compounds. Benzene derivatives, J. Am. Chem. Soc., 59 (1): 96-103 (1937). DOI:10.1021/ja01280a022.

[34] R. A. Y. Jones, Physical and Mechanistic Organic Chemistry, Cambridge University Press, 1979, pp. 35.

[35] T. M. Krygowski, Crystallographic studies of inter and intramolecular interactions reflected in aromatic character of $\pi$ elektron systems, J. Chem. Inf. Comput. Sci, 33, 70-78 (1993).

[36] T. M. Krygowski, J. E. Zachara, R. Moszynski, Theoretical study of changes in $\pi$-electron delocalization in the analogues of an ortho-hydroxy Schiff base when the proton is replaced with $\mathrm{Li}^{+}$or $\mathrm{BeH}^{+}$, J. Chem. Inf. Model., 45 (6), pp 1837-1841 (2005).

DOI: $10.1021 /$ ci0502911

[37] M. Odabaşoğlu, Ç. Albayrak, O. Büyükgüngör, H. Goesmann, 4-[(3-hlorophenyl)diazenyl]-2-\{[tris(hydroxymethyl)methyl]-aminomethylene \} cyclohexa-3,5-dien1(2H)-one, Acta Crystallogr., C59 o234-o236 (2003). DOI: $10.1107 / \mathrm{S} 0108270103006292$

[38] O. Şahin, Ç. Albayrak, M. Odabaşoğlu, O. Büyükgüngör, (Z)-3-Hydroxy-6-[(2-methoxyphenylamino)-methylene] cyclohexa-2,4-dienone, Acta Crystallogr., E61, o2859o2861 (2005). DOI: doi.org/10.1107/S1600536805024189

[39] Ç. Albayrak, G. Kaştaş, M. Odabaşoğlu, O. Büyükgüngör, Existence of a resonance hybrid structure as a result of proton tautomerism in $( \pm$ )-(E)-4-bromo-2[(2,3-dihydroxypropylimino)methyl]phenol racemate, Spectrochim. Acta A, 120, 201-207 (2014). DOI: http://dx.doi.org/10.1016/j.saa.2013.10.022

[40] Ç. Albayrak, G. Kaştaş, M. Odabaşoğlu, R. Frank, Probing the compound (E)-5-(diethylamino)-2-[(4methylphenylimino)methyl]phenol mainly from the point of tautomerism in solvent media and the solid state by experimental and computational methods, Spectrochim. Acta A, 81, 72-78 (2011). DOI:10.1016/j.saa.2011.05.046

[41] Ç. Albayrak, G. Kaştaş, M. Odabaşoğlu, O. Büyükgüngör, Probing the compound (E)-2-[(4bromophenylimino)methyl]-6-ethoxyphenol mainly from the point of tautomerism in solvent media and the solid state by experimental and computational methods, J. Mol. Struct., 1000, 162-170 (2011). DOI:10.1016/j.molstruc.2011.06.018

[42] Ç. Albayrak Kaştaş, G. Kaştaş, A. Güder, M. Gür, H. Muğlu, O. Büyükgüngör, Investigation of two o-hydroxy Schiff bases in terms of prototropy and radical scavenging activity, J. Mol. Struct., 1130, 623-632, (2017). DOI: http://dx.doi.org/10.1016/j.molstruc.2016.11.023

[43] Ç. Albayrak Kaştaş, G. Kaştaş, M. Gür, H. Muğlu, O. Büyükgüngör, Analysis of tautomeric equilibrium in (E)-4,6-dibromo-2-[(4-fluorophenylimino)methyl]-3-methoxyphenol compound, Spectrochim. Acta A, 151, 731738 (2015). DOI:http://dx.doi.org/10.1016/j.saa.2015.07.030 